\title{
Research about the Media Violence form and Its Channels of Communication in We-media Era
}

\author{
Yujie $\mathrm{Yao}^{1}$, Yun $\mathrm{Ke}^{2}$ \\ ${ }^{1}$ School of Media Communications, Linyi University, Linyi 276000, China \\ ${ }^{2}$ Wuhan technology and business university, Wuhan 430074, China \\ yujie@163.com
}

Keywords: We-media, media violence, traditional media.

\begin{abstract}
The appearance of We-media marks that the audiences participate in cultural communication and interactions. But due to some users' attainment of We-media literacy is very low, causing many problems produced in the information communication, of which the media violence is extremely obvious. And its means of transmission makes the violence information' communication damage compared with traditional media for the spread is larger and more difficult to be controlled. Based on this reason, this paper will study the problem of media violence, and the regulatory method is put forward.
\end{abstract}

\section{Introduction}

At present, the research on the present situation of media violence in our country, mainly were analyzed from the events in the news interview and processing and so on. Such cases are very common, for example, the bombing event in Boston reported in the United States, some Chinese media in the absence of any screening and techniques covered, directly in the form of images on the web site present a limb, blood such as pictures, to abandon ethical bottom line. Therefore, researchers put forward that news interview fills with terror, bloody. For example, the ABC reported that the Chinese consulate general in San Francisco encounters a deliberate arson, and after the crime, there has a "Tibetan human rights" logo in the building, but it could not determine whether the identity have something to do with arson. However, many of the media use their own domestic editing skills to make the fire and the Tibet independence directly related. For the matter, researchers pointed out that the news event be processed and been made a qualitative analysis of the media violence [1-3].

Above these vertical media violence analysis are lack of the deep analysis and fewer details. This article will combine the specific case to make a transverse analysis, including the details of the media violence forms. On the basis of the theory of media and communication methods of basic theory, to make a comprehensive analysis of media violence and its transmission characteristics. And finally we will analyze the harm of media violence and countermeasures.

\section{The Major Performance of Media Violence in the We-media Era}

Trial by We-media. The media trial of We-media is an extension of the traditional media trial in essence. It is using We-media to make a moral judgment for the party in the event. The media trial phenomenon is very common. For example, Guangdong Foshan 'little yue yue' event in 2011, a group called 'little yue yue' of a 2 years old girl were crushed by two cars. Before the little girl was saved, there are 18 passerby, but maybe due to fear or the mind of more or less attitude, they do not to rescue the little girl and chose to ignore, the little girl finally died. There will be much gnashing of teeth about the indifference of the impersonal, but they don't do any illegal things. However, after the incident, the 18 men on the Internet have suffered a relentless media trial. They meet with relentless abuse by netizens. Then, some netizens unwilling so let them off, so they launched the human flesh, their name, occupation, family address, and so on are all human flesh search engine, and are published on the Internet. Such behavior has seriously affected their normal life [4]. 
Be the Rumor COC. The generation and transmission of rumors is the inevitable outcome of the development of We-media. The information source and the correctness become difficult to grasp because of the loose media environment. As a result, rumors have the spread environment and its contagion becomes unable to stop. For example, Anhui "fetus stolen" event in 2013. It is reported that a pregnant woman was on the way to do physical checks were charmed in Tai He county, after she wake up, the baby was to be taken. But the case in the report is not from the mouth of the pregnant women, but a general insider revealed. The news command immediate attention from all kinds of the media on the network, including Weibo of the traditional media. These we-media and the website quickly forwarding the report. Which '@ CCTV news' to release the incident of the microblogging is forwarded nearly 5000 times, comments are more than 2000 times. Soon the police clarify that it is false and the truth is that there is not the pregnant. It can be found that the pursuit of the freshness of news and causing the attention of the audience, the traditional media actually neglected the authenticity of the news, and is not investigating the information source of the news whether is reliable. Then it contributed to the spread of rumors. As non-professional socialist news production, We-media more can't ensure the authenticity of information, then it will be easier to promote the spread of rumors [5].

Grouped Wars of We-Media. We-media war, especially the Weibo scold war is most typical and attracted attention. And the scold wars of some public figures in microblog microblogging are easy to cause concern. They are opinion leaders in microblog, such as the body entertainment star, experts and scholars, business and so on, they are outstanding person in microblog users, because their popularity identity they own tens of microblog fans. So their information is not only a purely personal opinion expression, more represents the opinions of a group. This determines their wars are destined to cause thousands of microblog users' comments and attention. If they run to scold, it will attract many fans onlookers, and then according to the position of their own that will be into the microblog yell. They will forward comment and be to attack each other, and there will be a propagation speed and the extent of impact, it can be conceivable.

\section{The Propagation Characteristics of Media Violence of We-Media}

The Severest and Viral Spread of Information. The propagation characteristics of the severest and viral spread is related to the interpersonal function of We-media. We-media allows free communication between the users, it can not only maintain daily interpersonal communication with familiar friends, but also establish interpersonal relationship with people who do not know, to expand your circle of contacts. As an open platform, such as microblog, it is a possibility of unlimited extension, it expanded the common meaning space between social members, users absorb vast amounts of information and influence each other and set up a special kind of social network relationships. The interpersonal in Weibo will eventually form a huge relationship network. There is a kind of six degrees of space theory, which thinks that people can establish contact between two strangers in the world through the broker in less than six people, that is, a person want to know another person in the world that he only needs through six people at most. When a man began to spread violence information, every one of the man in the circle of friends will receive. Repeat, violence information will keep fission spread like a virus, lead to thousands of microblog violence information transmission [6-7].

The Belt-breakage and Shelter of Information Spreading. Hidden information does not rule out some violence propaganda deliberately spread in this way the information, in order to achieve their purpose. Audience after watching these information, some of the audience would choose to ignore, but more audience will choose to condemn comments, seemingly maintained the microblogging good communication environment, in the middle of the hands of the poor are actually, help them spread the information of violence. Some audience heart actually not exclude or confused violence information, will help to forward and comment, thus contributing to the spread of violence information. In addition, since the media information spread fast, has had a huge impact, but they won't continue for a long time, it will appear a broken belt transmission. As we all know, one thing 
need to know the ins and outs of it need to collect all kinds of information, each stage of the information, will be able to complete. If not able to track to collect, will inevitably bring certain one-sided understanding, thus affecting the overall cognition. The transmission of information in the media violence is the use of such a media information dissemination limitations. First of all, it spread rapidly, and cause huge impact, let the audience to comment, but the spread of its subsequent development is often no more, follow-up is not development, cannot let the audience to form a comprehensive and objective understanding of events, finally will cause a tremendous negative impact.

\section{The Spread Environment Angle of We-media}

Loophole of Communication System of We-Media. When we registered in microblog, the condition is very simple. It is very diverse, which can be registered through mail, mobile phone number and id number. The id number registered is like real-name certification, essentially id does not need any validation. Then this does not rule out people with id number to register the others. Therefore, the so-called real-name system of sina microblog don't have much substantial significance. Also, registered email and mobile phone number registered, they also can use the new email, new telephone number registered on microblog, and a person has several microblogging accounts to be normal again. In this way, it gave the hidden conditions for violence information spreader. If they want to take a walk of false information or malicious remarks, microblog real-name system is not only has little effect to them, instead it has played a promoting role. Microblog real-name system although improves the quality of the twitter account, also increases the credibility of the false information.

Earthy of We-media Users. We-media users are more ordinary people, so that they care about social information, social hot issues, the country's political policy and social environment is inevitable. Because the focus points are the same, point of view of communication became very frequent collision, the contradiction becomes took it for granted. Plus the media literacy and moral quality of the common people is low, the level of violence is bound to produce. At the same time, among these grassroots users, there are some users to be sinister, they know about the media operation mechanism thoroughly, and they used the leaky mechanism to spread violence information on platform. Since other grassroots media users' personal media literacy deficiencies, leads to their identification ability of violence information is weak. Plus the gatekeepers' idea is missing in We-media era, it causes these violent information to spread without limit and it is quick. Some user spreads violence information unwittingly, just as the freedom of the media public opinion environment, let them speak without constraint and follow their inclinations. So when speaking with too much personal emotions, the content they promote is no moral integrity. In December 2010, for example, the microblog controversy between Fangzhouzi and Zhenyuanjie about the latter's works, the yangcheng evening news reporter chose the foremost 1000 comments, among these there are 509 comments with dirty words, directly or indirectly said to each other is the 'pig', 'cow', 'dog' and other animals, such comments have been more than 200 comments and so on.

\section{Harm of the Media Violence of We-Media}

Media Violence Trigger Real Violence. Now the We-media network has not satisfied with the simple written communication online, but pay attention to the combination of online and offline. The media violence of We-media is a kind of We-media information dissemination, it is also in accordance with this law. Therefore the media violence of We-media may be from the network virtual violence turned into reality violence. We can choose to free speech, the other people are also free to speak, but we can't control other people's information for the speech. In this way, the media violence information will show in front of you, and over time, this kind of violence information will turn into a real violence in all forms, such as human flesh search, microblog about frame and so on. In 'little yue yue' incident, the extreme net friend are dissatisfied with their behavior, thus they launch a human 
flesh for the 18 passerby, their name, occupation, family address, and so on are human flesh search engine and be published on the Internet, it seriously affecting their normal life. Among the 18 passerby, one by the name of Chen shen told reporters in the face of reporters, he often received a strange phone call, the phone content is almost a threat to his reviled and language. Net friend's human flesh search information exposure let him in the hardware market stall business is almost impossible to maintain.

Affect the Objectivity of Audience Cognition. In the We-media age, every Internet user has the equal opportunity to speak, we put those given by the opinion leaders than other communicators can more fully reflect problems, meet the demand of audience of information called advantage information. In the face of these advantages, We-media users' attention will because this is their own choice of information transmission to come over by opinion leader and choose to focus on, reviews and forward. And it is likely to set up a discussion group to surround and watch. Such unconscious discussion is not able to get effective rational analysis, on the contrary, it will thinking dominated by opinion leaders because of the unconscious. If the opinion leaders is for personal purpose, or the opinion leaders itself due to the limitations of knowledge, low level of media literacy, they will give the constructive opinion which is too extreme, then it will cause these objective cognitive users of We-media as a one-sided. In the Li Tian Yi event, for example, after the incident, actor Du Ge said in his microblog, according to the internal reliable news, the victim in the case plan to dismantle his complaint, because li and other suspects' parents promised the victim a high amount of material compensation, including the implementation of the Beijing registered permanent residence, job and a home. The microblogging has created quite a stir. In a very short period of time it was forwarded more than ten thousand times, has a great impact on public opinion, but finally it is proved this tweet is false, and it is a concoctive information by Du himself. In addition, everyone is the disseminator of information in We-media era, information from We-media is countless, vast amounts of information let the audience understand the complete event, at the same time, they also bring to the audience's cognitive confusion and make the audience's cognition, judgment and behavior have a significant impact. Therefore, the media violence of We-media will seriously affect the audience's cognitive objectivity, it is unable to make their own cognitive judgment.

The Mental and Physical Damage for the Audience. The media violence of We-media uses the network virtual space, irrationality and extreme language crusade against and attack others, the language is beyond the normal scope of review events, which will cause damage to clients' reputation. In 2011, for example, in the Guo meimei event, human flesh search is one of the typical audience examples which impact their real life. Users use modern means of science and technology, to make information query for the parties in the event, and widely published online. It makes the traditional network information search becomes relational social search. The characters in the virtual world are closely linked with real world, citizens' personal privacy and information is known by others, such as the infringement of citizens' rights at the same time, it also may bring inconvenience and disturbing factors of its life. After Guo flaunts wealth, her personal information was disclosed by netizens. It completely doesn't have any privacy, and Guo himself is attacked by netizens with a torrent of abuse.

Cognition Problem for the Media Violence. The direct cause of the media violence of we-media is we-media users who spread violence information, their media literacy is so low to directly harm the entire user community. Similarly, those we-media users who received violence whether can correctly realize the media violence and its harm, we also don't know. Today, most of users will not be independent of their views, they are in a collective unconscious, which is the unconscious has the upper hand, they are easy to be affected by the opinion leaders. If these opinion leaders have evil intentions, it is easy to lost their own nature and become an accomplice for the media violence. Knowledge of media violence and its harm, it is each Internet users need to have the quality.

\section{Countermeasures of Media Violence about We-media}

Public sentiment is easy to happen and show in the social events. In the absence of a mainstream public opinion, the mood is very easy to lose control or by use of someone with selfishness, and lead 
to the production of rumors and violence information. In the era of traditional media, as the information media gatekeepers, media editors will confirm the authenticity of news and information to ensure that the media news reports is truthful and accurate, and stop the spread of rumors. This makes the rumor can only be word of mouth in the interpersonal communication, it greatly restricted the rumors' spread speed and range. Into the we-media age, the completely open environment, speech transmission mechanism on the free review, forwarding, plus that the gatekeepers concept is missing, the spread of rumors becomes do not be controlled. In this case, we must be someone to guide public opinion, and the mainstream media as the media credibility has become very important. In the first step to use traditional media to guide public opinion, it is using the good social credibility of traditional media public events information. Guarantee the audience's right to know the truth, let the audience will be not careless suspicion, and there will be no rumors. The mainstream media is the eyes and ears of the government mouthpiece, when the incident happens, the government should publicly in the mainstream media event information, firstly to let the audience understand the truth of the matter and kill the rumor.

\section{Summary}

This paper discussed the spread characteristics, propagation environment and harm and regulation measures of media violence in We-media era. In particular, as one of the hottest media today, microblog is used as an example to be introduced in the paper, the above problem is discussed in this paper in detail. Through the study of this article, we hope to provide some reference and warning for the We-media users and be together to face the media violence.

\section{Acknowledgements}

This paper is a study of the social science planning project of Shandong Province in 2013, "The Study of Media Violence in Wemedia Age" (item No.: 13CXWJ01)

\section{References}

[1] Linda M. Sama, Victoria Shoaf. Ethics on the web: Applying Moral Decision-Making to the new media, Vol. 36 (2002) No.3, p. 93-103.

[2] Elizabeth J. Erwin, Naomi Morton. Exposure to Media Violence and Young Children with and without Disabilities: Powerful Opportunities for Family-Professional Partnerships, Vol. 36 (2008) No.3, p. 105-112.

[3] Chen Li Dan. Ten news theory(Fudan University Press, China 2008), p.14.

[4] Guo Qing Guang. Communication tutorial(Bejing: China Renmin University Press, China 2011), p.4.

[5] Li li tian. Research about Weibo violence, Vol. 16 (2013) No.4, p. 101-105. (In Chinese)

[6] Sun Ting. Infulence on group polarization phenomenon of Weibo, Vol. 12 (2013) No.5, p. 81-86. (In Chinese).

[7] Information on http://wenku.baidu.com/view/e2025bf09e3143323968937c.html. 